2. Кули Ч. Общественная организация. Тексты по истории социологии ХІХ-ХХ веков. - М.: Наука, 1994. C.167-169.

3. Куницына В.Н., Казаринова Н.В., Погольша В.М. Межличностное общение. Учебник для вузов. - СПб.: Питер, $2001-544$ c.

4. Роберт И.В. Теория и методика информатизации образования (психолого-педагогический и технологический аспекты) [Электронный ресурс] / И.В. Роберт. - Эл. изд.-М. : БИНОМ. Лаборатория знаний, 2014.—398 с.: ил. - (Информатизация образования).

5. Розина, И.Н. Педагогическая коммуникация в электронной среде / И.Н. Розина // Известия вузов. Северокавказский регион. Общественные науки. 2004. № 2. - С. 97-99.

6. Тетина, С.В. Методическая грамотность как часть профессиональной компетентности учителя иностранного языка / С.В. Тетина // Научное обеспечение системы повышения квалификации кадров: научнотеоретический журнал. - 2016. - №3 (28). - С.164 - 169.

\title{
Загоровская Н.В. \\ История изучения подвижных игр в русской педагогической мысли
}

Российский государственный университет физической культуры, спорта, молодежи и туризма

(Россия, Москва)

doi: 10.18411/trnio-09-2021-44

\section{Аннотация}

Подвижные игры являются средством физического воспитания с древних времен на различных возрастных этапах развития человека. В статье рассматриваются основные вехи изучения дисциплины «Подвижные игры» в рамках педагогики, обозначаются перспективы использования подвижной игры как воспитательного и образовательного метода в условиях современного общества.

Ключевые слова: игра, подвижные игры, педагогика, история подвижных игр.

\section{Abstract}

Outdoor games have been a means of physical education since ancient times at various age stages of human development. The article discusses the main milestones of the discipline "Outdoor games" study in the framework of pedagogy, outlines the prospects for the use of outdoor games as an educational method in the conditions of modern society.

Keywords: game, outdoor games, pedagogy, history of outdoor games.

С древних времен игра использовалась как средство воспитания детей и педагогическая модель для обучения человека необходимым для выживания и развития навыкам: общению, физической подготовке, охоте, ремесленному делу. Исследование игры позволяет понять механизмы взаимодействия людей более полно. Именно с точки зрения средства воспитания эстетического и нравственного на игру смотрели античные философы: Платон подчеркивал, что ее следует поддерживать в деятельности ребенка, потому что она подражание действительности, а Аристотель видел в игре гармонию души и тела, она существует для удовольствия и отдыха [1, с.376-644]. Игра у Платона не обладает истиной, но ее можно с помощью игры познать [13, с.4]. Кроме того, философ выделяет в игре несколько особенностей: она непредсказуема, несерьезна, свободна, призвана дарить удовольствие. В жизни древнего мира игры существовали в форме воспитательной и обрядовой. Причем у римлян в играх обязательно присутствовал компонент пользы, в своем трактате «Об образовании оратора» Марк Фабий Квинтилиан перечисляет игры, необходимые для обучения детей [6].

В Средневековье игра наиболее полно воплотилась в религиозных культах и смеховой культуре. Она, несмотря на все запреты, описанные, например, в трудах Аврелия Августина, продолжала существовать и в церковной среде: ритмомахия, подвижные упражнения, игры, входящие в учебную программу, занятия футболом и теннисом. В эпоху Возрождения взгляд 
культуры обратился к античности, что, безусловно, продолжило осмысление игры со стороны изучения еe положительных свойств на организм человека, воспитания необходимых волевых и физических возможностей, ее иносказательных смыслов, развивается и теория определенных игр: трактат Антонио Скэно об игре в мяч, пособие Джованни ди Барди, описания различных игр Инторнато и Сципиона Бергали.

Немецкий философ Фридрих Шлейермахер (1768-1834) видел игру как сферу «свободного общения», которая способствует повышению интеллекта, помогает человеку реализоваться и достичь внутренней свободы [17]. Ницше высказывал схожие взгляды и с Ф. Шиллером, говоря о том, что возрастающее увлечение игрой способствует возникновению новых миров [8, с.60-94], то есть влияет на развитие фантазии и творческих способностей. Джон Дьюи (1859-1952) разделял игру у ребенка и внешнюю деятельность, а так как игра характеризует психологическое состояние [5, с.18-31] видел в ней средство самовыражения. Именно с ее помощью человек может реализовать свой потенциал, получить признание в обществе, снять накопившееся внутреннее напряжение. Играя, человек учится взаимодействию с окружающим миром, вырабатывает модели преодоления сложных ситуаций.

Исследование игры также развивалось в трудах психологов и социологов. Зигмунд Фрейд (1856-1939) считал ее средством психического развития и познания себя, выражения эмоциональных реакций. Ребенок, играя, сам моделирует ситуации, контролирует степень впечатления, копирует поведение взрослого, компенсируя тем самым свое желание скорее вырасти [15]. Якоб Морено (1889-1974) противопоставил идее Фрейда об индивидуалистской природе игры игру в группе, видя конфликт не в человеке в самом себе, а в его взаимодействии с малыми группами. Морено создал психодраму как метод групповой терапии, способствующий освобождению от внутренних конфликтов при помощи игры [9]. Вильям Штерн (1871-1938), внесший значительный вклад в развитие психологии, ввел понятие «серьезная игра». Оно использовалось для характеристики действий подростка, стремящегося осознать собственную индивидуальность, это «промежуточные формы между детской игрой и серьезной и ответственной деятельностью взрослого» $[18$, с.20]. Карл Гросс (1861-1946) воспринимал игру как средство приготовления к жизни, из чего вытекает ее основная функция: дополнения действительности. Играя, человек получает те эмоции, которые в реальной жизни не испытывает или подавляет, следуя же процессу игры, мы не преследуем каких-то практических целей как в жизни при выборе дальнейшего сценария, а значит, испытываем большую свободу [4]. Ж. Пиаже (1896-1980) выделял несколько типов игр: игра-упражнение, символическая игра, игра с правилами [11].

В России исследованием игры занимались К.Д. Ушинский, П.П. Блонский, Л.С. Выготский, А.Н. Леонтьев, С.Л. Рубинштейн, Д.Б. Эльконин. К.Д. Ушинский (1823-1870) считал, что игра - это способ преобразования жизни. Для ребенка эта особая реальность игры интереснее, чем реальность, именно потому, что она понятнее. [14, с.432]. Для П.П. Блонского (1884-1941) игра - это действия ребенка, которые можно разделить на следующие виды: мнимые, строительные, подражательные, подвижные, интеллектуальные и игрыдраматизации [2, с.109]. Л.С. Выготский (1896-1934) писал, что игра - это переработка пережитых впечатлений, построение на их основе новой действительности, которая отвечает запросам и влечениям самого ребенка [3, с.7]. А.Н. Леонтьев (1903-1979) выделял особенности игры в зависимости от этапа развития человека, основным свойством игры как деятельности считал не получение конечного результата, а сам процесс [11, с.19-32]. Этапом, определившим новую ступень в изучении игры, стало написание Йоханом Хёйзингой (18721945) труда «Ноmo ludens» (1938) [16]. Он также выделяет ряд свойств игры: она добровольна, имеет границы места и времени, имеет заранее принятые правила, имеет цель в достижении радости и снятия напряжения, призвана создать бытие, отличное от повседневного. По Хёйзинге игра призвана поддерживать общественные связи, которые не ограничены формальным распределением ролей или, напротив, атмосферой близких отношений. 
Одними из трех выделяемых в педагогике видов игры наряду с творческими и спортивными являются подвижные игры. Отличительной особенностью подвижных игр является наличие определенного сюжета и истории, который позволяет в большей степени вовлекать участников в процесс. Мишенькина В.Ф. и другие авторы пособия «Подвижные игры» выделяют следующие отличия подвижных игр от спортивных.

- $\quad$ Подвижные игры используются лишь для общей физической подготовки без нацеленности на высокие спортивные достижения.

- В подвижных играх более гибкая система правил, которую можно варьировать в зависимости от ситуации в отличие от спортивных игр, в которых количество участников, размеры площадки и правила всегда строго регламентированы.

- $\quad$ В подвижных играх от участвующих не требуется специальная подготовка.

- $\quad$ В подвижных играх нет сложной тактики и техники игры.

- $\quad$ По подвижным играм не проводятся классификационные соревнования с присвоением спортивного разряда [12,с.7].

В древности развитие физических качеств в рамках воспитательного процесса было направлено на подготовку к повседневной жизни. Как пишет Джуринский А.Н., «... идеи воспитания откладывались в устном народном творчестве. Пословицы, поговорки и т. п. в художественной форме формулировали понятия, истины, наставления, поучения, пожелания, касавшиеся жизненных принципов, занятий хлебопашеством, бортничеством, рыболовством и пр.: держись за соху: она кормилица; без труда не вынешь рыбку из пруда, работа да руки надежные в людях поруки; добро творить - себя веселить и др.» И подвижная игра выступила определенным маркером культуры, объединяя в себе устное народное творчество и необходимое в повседневной жизни развитие физических качеств. С распространением письменности некоторые игры закреплялись и в этих источниках, однако систематизированы еще не были. В.В. Гориневский отмечает: «У всех народов существует более или менее значительный запас игр, характеризующих до некоторой степени быт народа» [7]. Отсутствие систематизации, таким образом, осложнялось и трудностью исследования огромного пласта игр различных народов России. Несмотря на упоминания в работах по педагогике на протяжении веков, особенно во второй половине XIX века (Н.И. Пирогов, Е.Н. Водовозов, П.Ф. Каптерев, подчёркивавших первостепенное значение подвижной игры как деятельности, отвечающей возрастным потребностям ребенка) и появлении к концу XIX началу XX века в трудах этнографов (А.Н. Рейнсон-Правин, Г. Новицкий), психологов (Д.Б. Эльконин) и других исследователей, это были лишь косвенные обращения к теме подвижных игр.

Наиболее подробные концепции изучения игры представили:

- К.Д. Ушинский (считал игру наиболее понятной и доступной формой познания мира для ребенка, а также то, что она вызывает живой интерес и зависит от окружающей среды. Отмечал значение комплексного подхода знания физиологии и психологии ребенка в педагогике, умственное развитие необходимо сочетать с физическим, применяя этот принцип на уроках на постоянной основе. Подвижные игры Ушинский предлагал использовать на уроках физического воспитания).

- Н. Филитис (сделал критический разбор теории игры Гутс-Мутса, считавшего, что игра - средство отдыха; игра для ребенка, как писал Филитис - один из способов познания мира, так как даже при изнеможении ребенок будет продолжать играть).

- $\quad$ П.Ф. Каптерев (игра - не только явление, бытующее среди детей, но и среди взрослых и животных; по Каптереву любая деятельность происходит или изза социально-культурных условий или естественно-органических. Дети больше подвержены влиянию последних, что приближает их к природе. 
Игра возникает в результате желания избавиться от нерастраченной энергии).

- $\quad$ П.Ф. Лесгафт (игру определял как упражнение, необходимое ребенку для подготовки ко взрослой жизни, с помощью которого вырабатываются важные моральные установки, воспитываются нравственные и лидерские качества. По Лесгафту у каждой подвижной игры должна быть цель, соответствующая в достижении возможностям и умениям для принесения в результате удовлетворения от деятельности. В процессе обучения подвижным играм их нужно усложнять постепенно, систематически развивая физические и морально-волевые качества, непреклонно следуя правилам для достижения развития. Именно с помощью подвижной игры по мнению Лесгафта возможно достичь воспитания характера, чувств товарищества, честности, самообладания).

- В.В. Гориневский (игра рождает положительные эмоции, которые оказывают положительное влияние на организм человека. Подвижная игра средство формирования личности - как физического, так и морального, потому что в ней обязателен сюжет, она подчинена методике и правилам, в игре присутствует соревновательный компонент, необходимость командного взаимодействия. Ученый уделял личности ведущего и его значении в проведении игры особое внимание).

- Е.А. Аркин (в подвижной игре видел основное средство дошкольного воспитания благодаря ее привлекательности для ребенка, способности к эмоциональному и физическому удовлетворению. Благодаря разнообразным движениям, подвижные игры не утомляют так быстро, как физические нагрузки, положительно влияют на воспитание психофизических качеств).

Итогом исследования подвижных игр на протяжении истории явились следующие выводы.

1. В основе многих игр исторически лежит деятельность взрослого человека.

2. При помощи подобного знакомства у ребенка формировались необходимые для дальнейшего успешного осуществления деятельности навыки.

3. Подвижные игры используются как средство воспитания не только физических, но и морально-волевых качеств.

4. При помощи подвижной игры ребенок учится взаимодействию с обществом и окружающим миром в комфортной и понятной для себя форме.

Сегодня подвижные игры составляют важную часть жизни ребенка, однако многие из них забыты. Перспективой развития становится совершенствование сюжетной линии некоторых игр с целью повышения внимания нового поколения детей, поиск путей популяризации забытых подвижных игр.

$$
* * *
$$

1. Аристотель. Политика // Соч. в 4-х т. - Т.4. - М.: Мысль, 1983. - С.376-644.

2. Блонский П.П. Педология. - М.: «Учпедгиз», 1934. - 356 с.

3. Выготский Л.С. Воображение и творчество в детском возрасте: Психологический очерк: Книга для учителя. — 3-е изд.- М.: Просвещение, 1991.- 93 с.

4. Гросс К. Введение в эстетику / К. Гросс. - Киев, 1989

5. Дьюи Д. Школа и ребенок. — М. 1923.- С. 18-31

6. Квинтилиан М.Ф. «О подготовке оратора» (отрывки). // Идеи эстетического воспитания. Антология в 2 т. Т. 1. Античность, Средние века. / Сост. С.С. Аверинцева. М., 1973

7. Кенеман А.В., Осокина Т.И., Детские народные подвижные игры - М.: Просвещение. 1989 - 239 с.

8. Королькова А.А. Тема игры в классической и неклассической философии: дис. канд. филос. наук. - СПб: 2010. - $177 \mathrm{c}$

9. Морено Я.Л. Психодрама / Пер. с англ. Г. Пимочкиной, Е. Рачковой. - М.: «Апрель Пресс»; «ЭксмоПресс», 2001. -528 c. 
10. Ортега-и-Гассет Х. «Дегуманизация искусства» и другие работы. Эссе о литературе и искусстве: Сборник. - М.: Радуга, 1991. - 639 с.

11. Пиаже Ж. Речь и мышление ребёнка. - М., 1994. - 526 с.

12. Подвижные игры: учебное пособие: [16+] / В.Ф. Мишенькина, О.С. Шалаев, Т.А. Колупаева, В.Ф. Кириченко; Сибирский государственный университет физической культуры и спорта, Кафедра теории и методики спортивных игр. - Омск: Сибирский государственный университет физической культуры и спорта, 2004. - 92 с.: схем., ил. - Режим доступа: по подписке. - URL: https://biblioclub.ru/index.php?page=book\&id=274873 (дата обращения: 22.08.2021). - Библиогр.: с. 69. - Текст: электронный.

13. Полное собрание творений Платона в 15 т. / Под ред. С.А. Жебелева, Л.П. Карсавина, Э.Л. Радлова. (Труды Петерб. филос. об-ва). — Пб—Л: Academia, 1922 Т. 1. Евтифрон. Апология Сократа. Критон. Федон. / Пер. С. Жебелева. - Пб, 1923. - 216 с.

14. Ушинский К.Д. Сочинения: В 11 т. - М.; Л., 1950. - Т. 8. - 776 с.

15. Фрейд 3. По ту сторону принципа удовольствия. Психология масс и анализ человеческого «Я» / 3. Фрейд. Харьков: Фолио, 2009. - 286 с. - Режим доступа: по подписке. - URL: https://biblioclub.ru/index.php?page=book\&id=227336 (дата обращения: 18.08.2021)

16. Хейзинга, Й. Нomo Ludens / Человек играющий: ст. по истории культуры / пер. с нидерланд. и сост. Д.В. Сильвестрова. - 2-е изд., испр. - М.: Айрис-пресс, 2003. - 486 с.

17. Шлейермахер Ф. Герменевтика. - СПб, «Европейский дом», 2004. - 242 с.

18. Штерн В. «Серьезная игра» в юношеском возрасте // Психология подростка: хрестоматия. / Сост. Ю.И. Фролов. М.: Российское педагогическое агентство. 1997. С. 20-32.

\section{Заневский Р.В. \\ Исследование способов подбора персонала для системы дополнительного образования} ФГБОУ ВО «Вологодский государственный университет» (Россия, Вологда)

doi: 10.18411/trnio-09-2021-45

Научный руководитель: Тяпин И.Н.

\section{Аннотация}

В статье рассматриваются проблемы кадрового обеспечения дополнительного образования, которым в настоящий момент не уделяется должного внимания, что, в частности, показало время карантинных ограничений (удаленная организация образовательного процесса). В связи с курсом России на цифровизацию, в том числе и образования, повышаются требования к педагогам дополнительного образования, что ведет к необходимости оптимизации кадрового подбора. Предлагается законодательно закрепить ключевые компетенции педагогов дополнительного образования. Эффективное кадровое обеспечение системы дополнительного образования - это стабильно действующий процесс кадрового подбора, нацеленный на формирование высококомпетентных педагогических кадров, способных выполнять целевые установки концептуальных основ развития дополнительного образования детей в Российской Федерации.

Ключевые слова: дополнительное образование, кадровое обеспечение, подбор кадров, оптимизация, профессиональные компетенции, профпригодность, тестирование, адаптация.

\section{Abstract}

The article deals with the problems of staffing of additional education, which at the moment does not pay due attention, which, in particular, has shown the time of quarantine restrictions (remote organization of the educational process). Due to the course of our country on the digitalization of the economy, including education, the requirements to teachers of additional education increase, which leads to the need to optimize staffing. It is proposed to legislate the key competencies of teachers of supplementary education. Effective staffing of the supplementary education system is a stable staffing process aimed at the formation of highly competent teaching staff capable of fulfilling the target settings of the conceptual framework for the development of supplementary education for children in the Russian Federation.

Keywords: supplementary education, staffing, staff selection, optimization, professional competence, aptitude, testing, adaptation. 